\title{
Caudofrontal Depression on the Cornual End of the Temporal Line of the Skull of Goat Breeds in Nigeria
}

\author{
Depresión Caudofrontal en el Final del Cuerno de la Línea Temporal del Cráneo \\ de una Raza de Cabra en Nigeria \\ "Olopade, James Olukayode; "Onwuka, Silas Kalu; **Kwari, Hyelduku Danladi \& *Oke, Bankole Olusiji
}

OLOPADE, J. O.; ONWUKA, S. K.; KWARI, H. D. \& OKE, B. O. Discovery of a depression on the cornual end of the temporal line of the skull of goats breeds in Nigeria. Int. J. Morphol., 24(3):349-350, 2006.

SUMMARY: A comparative study of skull types was done using 65 skulls obtained from three different goat breeds in Nigeria namely; Red Sokoto, Sahel and West African Dwarf. A unique depression was consistently found at the cornual end of the temporal line of the skull medial to the middle portion of the caudal boundary of the orbit and dorsal to the lateral portion of the parietofrontal suture. The depression was found in all the breeds studied, and in both sexes on the lateral sides of both cornual processes of the frontal bones. The features (depth, height and width) of the depression were found to vary without regard to either sex or breed.

A search of the literature did not yield any information on this depression in the skull of the goat. Consequently, we venture to name this depression, the caudofrontal depression.

KEY WORDS: Skull; Goat breds; Caudofrontal depression.

\section{INTRODUCTION}

Morphometric studies of the skull have been documented in many domestic animals such as the dog (Onar, 1999), cat (Kunzel et al., 2003), pig (Endo et al., 2002). Except for the work done by Olopade (2003) and Olopade \& Onwuka (2005), there is a dearth of information on morphometric studies of the skull of goats in Nigeria; studies which could be important in anthropology (Bokonyi, 1974), regional anesthesiology (Olopade \& Onwuka), taxonomy (Habel, 1975) and comparative anatomical studies between and within breeds. These studies are also important in classification as phenotypic appearance of an animal's head has been reported to depend on the shape of the skull and strongly related to breed-specific skeletal features (Kunzel et al.).

In an effort to provide baseline descriptive data on the skull of goats we carried out morphological studies on the bones of the skull of goat breeds in Nigeria and hereby report a unique finding observed in the study.

\footnotetext{
* Department of Veterinary Anatomy, University of Ibadan. Nigeria.

${ }^{* *}$ Department of Veterinary Anatomy, University of Maiduguri, Nigeria.
}

\section{MATERIAL AND METHOD}

A total of 65 goats of the Sahel, Red Sokoto, and West African Dwarf breeds were used for this study. The goats were aged and thereafter slaughtered and the skulls macerated according to the techniques described by Olopade $\&$ Onwuka. The study done then encompassed the morphological description of all bones of the skull.

\section{RESULTS}

A depression in the temporal line of the skull was found precisely in the cornual end of the line medial to the middle portion of the caudal boundary of the orbit (Figs. 1 and 2), and dorsal to the lateral aspect of the parietofrontal suture. This depression was found in all the three goat breeds and in both sexes on the lateral sides of both cornual processes of the frontal bones (Fig.2). There was, however, no sex or breed peculiarity in the features of the depression. 


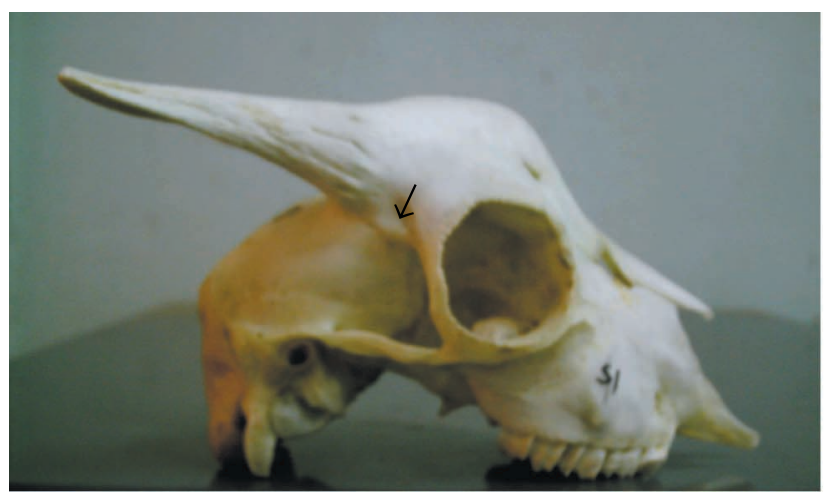

Fig. 1. Arrow showing a caudofrontal depression in the skull of a goat.

\section{DISCUSSION}

Regional anatomy is directly concerned with the form and relationships of all the organs present in a particular part or region of the body. The shape and appearance of the head is important in determining the character of the animal (Dyce et al., 1996).

The depression seen in the temporal line in all goat breeds in this study has to the best of our knowledge, not been reported before in the literature and thus, its clinical significance is yet to be known. A comparison with museum specimens however revealed that this depression was not seen in the pig, dog cattle, man and antelope but appears far less distinct in the sheep.

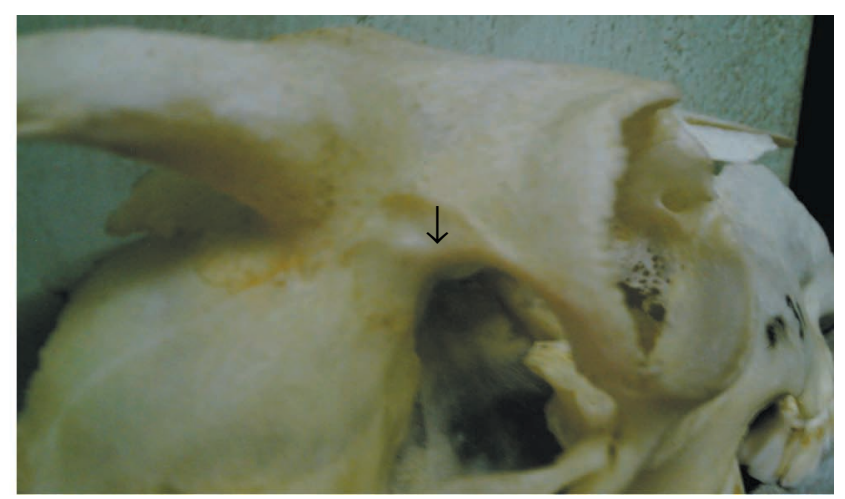

Fig. 1. Arrow showing a caudofrontal depression in the skull of a goat.

Morphological landmarks in the head particularly the skull have been used to distinguish breeds and species (Dyce et al.; Kunzel et al.)

Although the features of this depression (depth, height and width) did not show any specificity to breed, sex and age, it was unique to the species and can thus be an aid in distinguishing the goat from other species in fossils and archeological sites, and in comparative anatomical studies.

In the light of the fact that this depression has not been described before in the literature, we venture to name it the caudofrontal depression (of Olopade).

OLOPADE, J. O.; ONWUKA, S. K.; KWARI, H. D. \& OKE, B. O. Depresión caudofrontal en el final del cuerno de la línea temporal del cráneo de una raza de cabras, en Nigeria. Int. J. Morphol., 24(3):349-350, 2006.

RESUMEN: Un estudio comparativo fue efectuado en 65 cráneos obtenidos de tres diferentes razas de cabras en Nigeria: Red Sokoto, Sahel y West African Dwarf. Una única depresión fue encontrada en el final del cuerno de la línea temporal del cráneo medial, al límite de la porción media con la caudal de la órbita y dorsal a la porción lateral de la sutura frontoparietal. La depresión fue encontrada en todas las cabras estudiadas, en ambo sexos, en el lado lateral de ambos procesos corneales de los huesos frontales. La medidas (profundidad, altura y ancho) de la depresión no tenían relación con edad o sexo de las razas de cabras.

La literatura no aportó ninguna información de la depresión en el cráneo de la cabra. Por lo tanto, proponemos denominarla depresión caudofrontal.

PALABRAS CLAVE: Cráneo; Razas de cabras; Depresión caudofrontal.

\section{REFERENCES}

Bokonyi, S. History of Domestic Mammals in Central and Eastern Europe. Akademiai kiado, Budapest, 1974. pp 597.

Dyce, K. M; Sack, W. O \& Wensing, C. J. G. Textbook of Veterinary Anatomy. $2^{\text {nd. }}$ ed. Philadelphia, Saunders, 1996.

Endo, H.; Hayashi, Y.; Yamazaki, K.; Motokawa, M.; Pei, J.; Lin, L.; Chou, C. \& Oshida, T. Geographical Variation of the Mandible Size and Shape in the Wild Pig (Sus scrofa) from Taiwan and Japan. Zoological Studies, 41(4):452-60, 2002.

Habel, R. E. Ruminant Introduction. In The Anatomy of the Domestic Animals. (Sisson \& Grossman eds). $5^{\text {th }}$. ed. Philadelphia, Saunders, 1975.

Kunzel, W.; Breit, S. \& Oppel, M. Morphometric Investigation of breed specific features in feline skulls and considerations on their functional implication. Anat. Hist. Embryol., 32(4):218-23, 2003.
Olopade, J. O. The Morphometry of the craniofacial and maxillofacial regions of the West African Dwarf Goat (Capra hircus). M.Sc. thesis, Department of Veterinary Anatomy, University of Ibadan, Ibadan, Nigeria, 2003.

Olopade, J. O. \& Onwuka, S.K. Some Aspects of the Clinical Anatomy of the Mandibular and Maxillofacial Regions of the West African Dwarf Goat in Nigeria. Int. J. Morphol., 23(1):33-6, 2005.

Onar, V. A morphometric study of the skull of the German shepherd dog (Alsatian). Anat. Histol. Embryol., 28, 253-6, 1999.

Correspondence to:

Prof. Dr. Iames OluKayode Olopade

Department of Veterinary Anatomy

Faculty of Veterinary Medicine

University of Ibadan

Nigeria

Email: jkayodeolopade@yahoo.com
Received: 21-03-2006

Accepted: 10-07-2006 